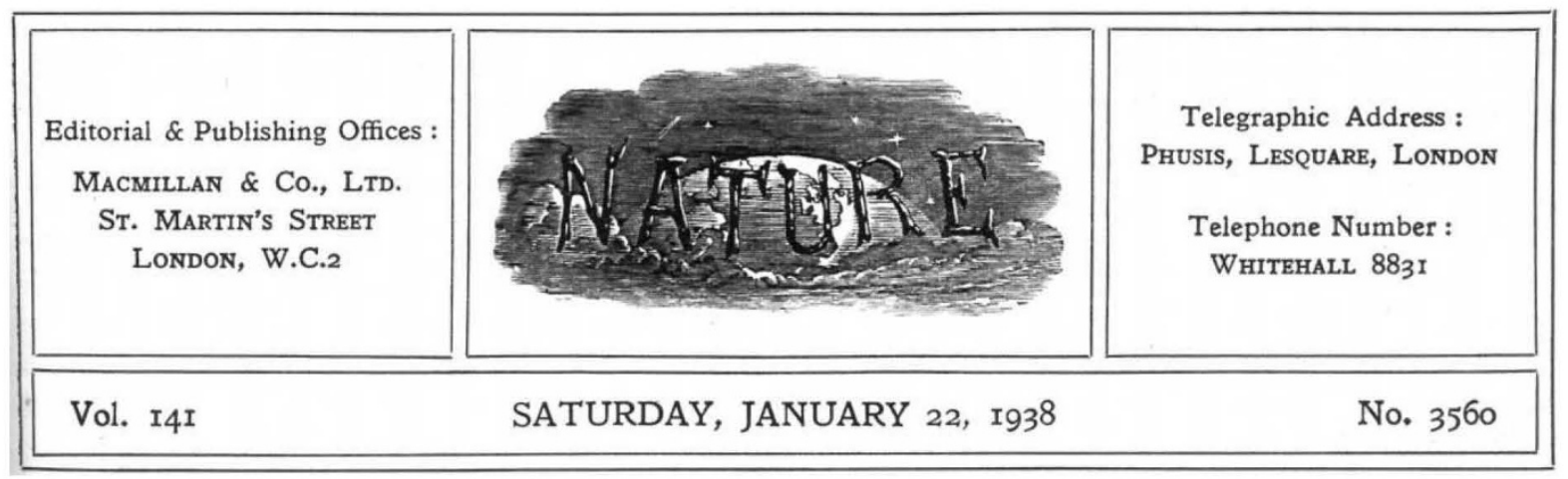

\title{
Realistic Social Studies
}

$\mathrm{I}^{\mathrm{N}}$ $N$ so far as it will be concerned with realistic study of contemporary issues, the new Institute of Economic and Social Research under the direction of Prof. N. F. Hall, the formation of which was announced in NATURE of January 8, is a venture which has the warm support of many scientific workers. The joint contributions of the Halley Stewart Trust, the Pilgrim Fund, the Leverhulme Fund and the Rockefeller Foundation should guarantee enough for starting a modest programme, which will rehabilitate the prestige of social research in Great Britain, if the personnel and problems are wisely chosen.

Thirty years ago the voluminous and pioneer studies of the Webbs, and the foundation of the London School of Economics, aroused high hopes of a new temper of inquiry. The sequel has been disappointing. Since then, social studies in Britain have been dominated by the dreary and barren dialectical tradition of deductive economics. Like astronomy in the medieval universities, political economy in our leading centres of higher education is still following the trail of selfevident principles. This being so, it is not surprising that responsible bodies which administer funds for research have been loth to make large allocations to university departments, or have refused to renew temporary grants such as the Rockefeller subsidy to the London School.

In his recent farewell address to the latter, Sir William Beveridge compared the state of the social sciences to anatomy before Harvey. Without immodesty, he might have drawn a moral from the generation which followed Harvey's work. The most conspicuous example of healthy growth in contemporary social research is the study of population on the lines initiated by three men whose names appear on the list of original fellows of the Royal Society. The pioneers of British demography were Graunt, Sir William Petty and Halley. Graunt figures as the "ingenious author of the Mortality Bills" in the first history of the Society by Sprat, Lord Bishop of Rochester. Halley published the first life table, in the Philo. sophical Transactions of 1693 . Since the first meetings of the 'Invisible College' were in Petty's rooms, the author of the "Politicall Arithmetick" shares with the "father of chemistry and the uncle of the Earl of Cork" the honour of being one of the first parents of the Society. Thus quantitative and realistic social inquiries shared in the efflorescence which followed Harvey's death.

After the lapse of little more than a century, Bentham exclaimed, "compare the state of chemistry then and now !" He might well do so. Chemistry in Bentham's time had just thrown off the self-evident principles involved in phlogistonism, and demography had taken up the self-evident principles of the gloomy parson. In his own day, Bentham's appeal for the reunion of naturalistic and humanistic inquiry made no ripple on the complacency of classical humanism in the established seats of learning, where the teaching of natural science prompted Babbage, Lucasian professor in the Newtonian succession, to write "The Decline of Science in England". No twentieth-century Babbage has appeared to compose a new "Economy of Manufactures".

Still, there are new signs of uneasiness about humanistic studies, and researches on population have become the focus of a new rapprochement between natural science and social studies. As in the times of Graunt, Halley and Petty, the new 
school of research draws its personnel from workers trained in the former. Revival of interest in population problems in Britain was initiated by the influence of two men. Sir William Beveridge graduated in astronomy: Carr-Saunders, his successor at the London School, was a professional biologist at an earlier stage in his career. The most challenging investigation of the British prospect has been that of Dr. Enid Charles in the Department of Social Biology of the School.

Such reflections might well justify the hope that the new Institute will welcome advice from men of science and recruit its personnel from scientific workers. So far, we have had no indication that it will. This is the more curious in view of the place which Sir Josiah Stamp occupies as its new president. In his British Association address, Sir Josiah urged, and rightly urged, that the "Impact of Science on Society" is the central theme of fruitful inquiry into current affairs. To his recently published volume of addresses he has added an appendix on research finance prepared for him by one of his scientific friends. None should know better the relevance of naturalistic knowledge to contemporary social research, and none should know better the value of closer co-operation between those engaged in realistic social inquiries and those who have a wide experience of the financial needs of large-scale research work. If the new Institute is going to tackle the fundamental problems arising from the way in which expanding technical resources react upon, and are used by, existing social institutions, the existing departments of economics in our universities will not supply the recruits which it needs most. If it is not going to tackle these problems, it will do little to reinstate confidence in social research under academic auspices.

\section{Elementary Geometrical Optics}

(I) Practical Physics for Inter. B.Sc. Students By Dr. H. M. Browning and L. Starbuck. Pp. $x+146$. (London, Glasgow and Bombay: Blackie and Son, Ltd., 1936.) $3 s$. $6 d$. net.

\section{(2) A Textbook of Light}

By L. R. Middleton. Second edition. Pp. viii +288 . (London: G. Bell and Sons, Ltd., 1937.) $6 s$.

(3) Light

By Vivian T. Saunders. Third edition. Pp. vii + 328. (London: John Murray, 1937.) $6 s$.

\section{(4) A Textbook of Light}

By G. R. Noakes. Pp. viii +355 . (London: Macmillan and Co., Ltd., 1937.) $6 s$.

(5) Elementary Physics :

for Medical, First Year University Science Students and General Use in Schools. By G. Stead. Fifth edition. Pp. $\mathrm{xv}+559$. (London: J. and A. Churchill, Ltd., 1936.) 12s. $6 d$.

\section{(6) College Physics}

By Prof. John A. Eldridge. Pp. $x+616$. (New York: John Wiley and Sons, Inc.; London: Chapman and Hall, Ltd., 1937.) 18s. 6d. net.

IN 1934 a committee of the Physical Society I published a valuable report on the teaching of geometrical optics. The committee made a unanimous recommendation with regard to the convention to be observed for the sign of the power of an optical system. This convention is universal among opticians, and may be expressed briefly by saying that a positive lens tends to converge and a negative lens to diverge the light. A more difficult problem to solve is that of obtaining agreement as to the sign conventions to be adopted when discussing the relations between object and image. Two alternative methods were adrocated, which may be called the Cartesian and the nonCartesian systems.

The committee expressed the opinion that the preference for one or other of these systems in elementary teaching should rest on experience with both in the schools. It is accordingly a matter of interest, and indeed of considerable importance, to determine to what extent older conventions have been discarded and which of the proposed alternatives seems likely to be adopted. Most of the school text-books, and those used in junior university courses, formerly agreed in assigning a negative focal length to a converging thin lens. Distances on one side of the lens were considered positive, those on the other side negative, and distances were considered positive when measured in a direction towards the source of light.

(1) This 'old' convention, which we shall call convention $A$, is still employed in the recently published "Practical Physics" for Intermediate Science students written by Browning and Starbuck. (2) In the second (revised) edition of his "Textbook of Light", Mr. Middleton, of Latymer Upper School, has done a useful piece of work 